\title{
Facilities of Basic School in Sanggau Kalimantan Barat Regency
}

\author{
Mawar ${ }^{1}$, Retnowati Wahyuning Dyas Tuti ${ }^{2}$, Nida Handayani ${ }^{3}$, Muhammad Syahrul ${ }^{4}$ \\ \{mawar22@gmail.com ${ }^{1}$, retnowatiwdtuti@yahoo.com², nidakrw@gmail.com ${ }^{3}$, \\ arulbima367@gmail.com $\left.{ }^{4}\right\}$ \\ Universitas Muhammadiyah Jakarta, Indonesia ${ }^{1,2,3,4}$
}

\begin{abstract}
Education upbringing is one requirement that must be fulfilled by the state, especially education in the state border which incidentally was very isolated, even many Indonesian border areas that have not received a decent education. The purpose of this study was to analyze elementary school facilities and infrastructure services in SD Negeri 24 Selangai, Sanggau Regency, West Kalimantan and to find out what the driving and inhibiting factors were. The analysis knife used is theory. This study uses a descriptive method with a qualitative approach. Data was collected by way of interviews, observation, and documentation. Data analysis uses the Analysis Model of Miles and Huberman. The results of this study indicate that the quality of service facilities and infrastructure at SD Negeri 24 Selangai in Sagau Province is still very poor. Can be seen from the condition of the school, one classroom is used for two study groups, the teacher's room does not have, the principal's room does not have, local only 3 for 6 study groups. The teacher is only 4 people. The attention and seriousness of the regional government and the government are lacking. SD is bordered by Malaysia.
\end{abstract}

Keywords: Services, Infrastructure Facilities, Elementary Schools.

\section{Introduction}

Education is a breaker of poverty, that's a very encouraging sentence to be better. Because it cannot be denied that education is indeed very important for someone to achieve success, the government program also requires the community to be able to take 9 years of education. Especially for priority locations on state borders. That becomes the most important thing in development priorities, especially in terms of education. In this case primary school education is the most spearhead to be able to start education by taking 9-year compulsory education. The problems in the world of education in remote areas and regions lagging behind, and the border (called $3 \mathrm{~T}$ ). But with the limitations of financing and various existing regulations, it is always used as an excuse to delay solving this crucial problem. Some concrete issues in this regard are how difficult it is to place teachers in the border area, the difficulty in establishing educational facilities and educational standards because of communication difficulties or lack of teaching aids in the teaching and learning process.

A reality that can be observed among public officials and political talk about the area of the border, so the border area into a serious concern and important for government. If all this time there has been an assumption that the border region is the "back porch" and has now been changed to "the front porch". The issue is how to change the view of several projects were entered into the border region still speckle significant impact on improving the welfare of 
people who require the attention of a serious of various parties. These conditions include those experienced by SD Negeri Number 24 Selangai, Sekayam District, Sanggau Regency, West Kalimantan Province.

\subsection{Formulation of the problem}

The formulation of the problem in this study is as follows:

1. How are the infrastructure services at SD Negeri 24 Selangai, Sanggau Regency, West Kalimantan?

2. What is the driving and inhibiting factors?

\subsection{Prior Eligibility}

First, results of the research Samion and Samion [1], revealed that the urgency of the management and care policy and implementation of the government in developing human resources Entikong through education sector is needed. Improved good coordination between fellow managers and educators. Increase access to information. Conduct regular data collection evaluations for administrative purposes as well as recapitulation of data collection on the completeness of learning implementation. As a means of monitoring and evaluation for the parameters of the success of the Education program and in taking policies as a follow up. Participating in the provision of facilities and infrastructure in conducting procurement in stages related to the completeness of supporting the implementation of learning.

The second research result, A'ing [2], this research aims to find out the development of education in the border area, to describe the development of education in the border area. This type of research is a qualitative descriptive study with key informants and informants as the Head of BAPPEDA of Malinau Regency, Head of Education in Malinau District and information from Kayan Hulu Sub-district Head, School Teachers, Community Leaders, and Kayan Hulu Communities. This research was conducted in the Kayan Hulu District of Malinau District with data collection techniques, namely through interviews, observation, documentation, and library research by using interactive model data analysis techniques. Based on the results of research show that development in the field of education in the border areas Kayan Hulu Subdistrict experiencing shortages in some school in the placement of teachers in each school still not evenly distributed. In the recruitment of teachers, the system used is: 1). the teacher takes the CPNS test, 2). for contract workers to take a test carried out by the temporary Education Office for 3). Honorary immediately gave a request for a job payment to the intended school. D sphere of development of educational facilities are still many schools that do not have educational facilities such as libraries, official residences of teachers and school buildings are adequate to support Operations School in relief is very balanced with coaching and debriefing good management and proper in order and the amount of assistance provided is not enough to meet all the needs of schools in the border areas because it is influenced by the conditions of distant areas.

Results third, Asri [3], argue education development as sector featured is an appropriate strategy in building the nation. Because education is a human resource product quality, which has the power of science $\mathrm{g}$ for survival build the nations. The purpose of this research is to get an overview of the forms of programs/activities that have been carried out by the central and regional governments, the forms of community participation, the condition of the community and the implementation/management of education by education actors in border areas. Based on the results of the study obtained a portrait of education at the border is: (a) Less than $60 \%$ 
of teachers in border areas who have appropriate teaching qualifications. (b) Around $80 \%$ of those whose career paths are borderline are not good. (c) teacher certification program must reach about $10 \%$ of teachers. (d) more than $40 \%$ of teachers teach more than two subjects, this shows the lack of teachers or lecturers' distribution uneven. (e) Facilities and support facilities for learning in schools are still low. (f) Another problem that is allegedly also contributing to the quality of education at the border is that teacher performance monitoring is still low. Some positive things, among others, such as the motivation of children to attend lessons are quite high, as well as the attention of parents to children's education, but the facilities and infrastructure as well as educational facilities that should be held by schools and by parents of students still cannot be fulfilled. Based on the APM and APK in Nunukan and Kutai Barat districts, the compulsory education program has been completed, but the government needs to provide adequate facilities for completing this program. Based on the results of this study it is recommended that the central and regional governments must think about learning facilities and facilities as well as good human resources as managers of education to improve the quality and equitable distribution of education in border areas.

From the three previous studies above, it can be concluded that the portrait of education in the border area (priority location) is still very alarming. The condition of education there is still very inadequate starting from the condition of school buildings, access roads, facilities and infrastructure as well as teaching staff who still need the main attention of the government. The difference with this Selangai Public Elementary School study is that road infrastructure is in place even though it is not all paved, certainly not difficult to reach by the local government. But the local government still has minimal assistance. His commitment is very lacking. This is the novelty or novelty of this research.

\subsection{Services}

Public services according to Roth [4], public service did fill in as the services available to the public, both in general (such as in a museum) or specifically (such as restaurant meals). Parasuraman, Zeithaml and Berry [5] said what is meant by service is:

"Service is all economic activities whose output is not a physical product or construction is generally consumed at that time is produced and provides added value in form (such as convenience amusement comfort or health.

Furthermore Parasuraman, Zeithaml and Berry [5] states that the quality of service is determined by two things, namely: expected service and perceived service. These two things are determined by the 5 dimensions of service quality, namely:

a. Direct evidence, namely the ability of a company to show its existence to external parties. The company's appearance and capabilities, facilities and infrastructure and the condition of the surrounding environment are tangible evidence of the services provided by the service provider.

b. Reliability, namely the ability to provide the promised service immediately, accurately and satisfactorily. Performance must be in accordance with customer expectations which means timeliness, the same service for all customers without errors, sympathetic attitude and high accuracy.

c. Responsiveness, which is a willingness to help and provide services that are fast (responsive) and appropriate to customers, by delivering clear information. Letting customers wait without a clear reason causes perception in the quality of service. 
d. Guarantee, namely knowledge, politeness, and the ability of company employees to grow the trust of customers to the company.

e. Empathy, which gives sincere and individual or personal attention given to customers by trying to understand the desires of consumers. Where a company is expected to have understood and knowledge about customers, understand customer needs specifically, and have a comfortable operating time for customers.

Public service according to Law 25 of 2009 is a public service is an activity or a series of activities in the framework of meeting service needs in accordance with statutory regulations for every citizen and resident of goods, services, and/or administrative services provided by public service providers. There are 3 types of public services, namely:

1. Administrative Services

It is a service in the form of providing various forms of documents needed by the public for example: making a Resident's Identity Card (KTP), land certificate, Birth Certificate, Death Certificate, Owner's Book of Motorized Vehicles (BPKB), Motorized Vehicle's Number (STNK), Building Permit (IMB), passport.

2. Goods Services

Goods services that generate various forms / types of goods into the public needs, include: telephone network, electricity supply, water supply.

3. Services are services that produce various forms of services that are needed by the public, for example: education, health care, transportation, postal services, sanitation, waste management, drainage, roads and sidewalks, parking, disaster response to floods, earthquakes, volcanic eruptions and fires, services social (insurance or social security).

\section{Research Methods}

The approach used in this research is a qualitative approach, so that social phenomena that cannot be explained quantitatively can be analysed. Data collection techniques are done through observation, interviews and documentation. While the informants for the interview were selected by purposive sampling, consisting of 4 Informants 1 School Principal and 3 Teachers so that the information obtained could answer the research objectives. Data analysis techniques use the analysis model of Miles and Huberman [6].

\section{Results and Discussion}

Based on the results of research that has been done, it can be seen from the results of the five indicators as follows:

a) Tangibles

Judging from the condition of the school buildings, it was really inadequate, because there were only 3 rooms in the classrooms that were divided up to be filled by 6 study groups. School facilities were not fulfilled, access to the school roads was very difficult. Facilities such as benches and tables are also inadequate. Human resources are also very minimal, because there are only 4 teachers who teach 6 class groups and one school principal. And the reason the local government does not distribute aid to 
primary schools in Sanggau district is because there are only 72 students there. It is a small amount compared to the number of other primary schools, but if the assistance and improvement of facilities and infrastructure facilities is not possible the number of students will increase significantly. Moreover, access roads that are far and difficult to go to make the surrounding communities do not deign to send their children to school.

b) Reliability

In terms of the ability and reliability of the government in providing services to the community specifically its primary schools in Sanggau district are still lacking. Because they rarely receive assistance from the government despite trying to apply for help. Governments that should have their responsibilities and obligations to pay attention to priority locations are not considered at all. Whereas in this case the role of government is needed by them, the elementary school community of Sanggau District.

c) Responsive

The ability to provide service accurately and appropriately considered at all has not been received by the school district elementary schools Sanggau because conditions are still very concerned not reflect responsive indicator of the government.

d) Assurance

The government's ability to provide guarantees at once is never felt by them. So far they only get help only in the form of the construction of libraries and houses for teachers' residences. Communication between regional governments is also not very good, because local governments rarely visit the Sanggau district's primary school because access roads to locations are difficult to reach. Communication from the school principal in the Musrenbang forum with the village government was also never realized.

e) Empathy

Assertion of government described by Parasuraman theory was not applied right in Sanggau district elementary school. Because they also rarely receive help to create an atmosphere of learning and teaching that is appropriate and comfortable. In this case the government requires firmness to be able to immediately provide assistance to be able to improve education in the district of Sanggau. So that life in the district of Sanggau can be better.

\subsection{Supporting and Inhibiting Factors}

In terms of primary school services in the district of Sanggau, there are the following supporting and inhibiting factors:

a) Supporting Factors

- 9-year compulsory education.

- Schools are very much needed in the area. Because the distance between one school to another is very far.

b) Inhibiting Factors

- $\quad$ Road access is very far and difficult to be taken by the surrounding community.

- The teaching staff is still lacking and limited.

- Inadequate physical condition of the building.

- Small number of students. 
- Infrastructure is very insufficient. Like decent classrooms, desks and study benches.

The lack of attention from the government, especially the local government which is actually closer to being able to directly involve them in providing assistance.

\section{Conclusion}

From the research that has been conducted based on five indicators of Parasuraman consisting of: tangibles, reliability, responsive, assurance and empathy we can conclude that the services of the government and or the local governments to the primary school at SDN 24 Selangai District of Sekayam Sanggau still bad. Although access roads are not so difficult anymore. Commitments from the regional and central government are still lacking.

\subsection{Suggestion}

Based on the research results above, it can be suggested:

a) The local government can collaborate with the closest tertiary institution;

b) Commitment is increased, often visited;

c) Talk about alternative help from non-government;

d) CSR Improvement;

e) Teachers and classrooms need to be added;

f) Students need to be trained in hygiene cooperation so that baby's feces are not all the way to the school and school grounds;

g) Teachers need to follow capacity building.

\section{References}

[1] Y. D. Samion; Samion, "Portrait of Education and Teacher Competence in the Border Region of Sanggau Regency," J. Res. Dev. Public Serv., vol. 3, no. 1, 2016.

[2] A. A'ing, "Study of Educational Development in the Border Region of Kayan Hulu District, Malinau Regency," Integr. Gov., vol. 3, no. 4, pp. 545-559, 2015.

[3] S. Asri, "Equality and Education Quality Improvement Policy in Border Areas," J. Educ. Teach., vol. 1, no. 1, 2017.

[4] G. J. Roth and B. Mundial, The private provision of public services in developing countries. Oxford University Press New York, 1987.

[5] A. Parasuraman, V. Zeithaml, and L. L. Berry, "Delivering quality service: Balancing customer perceptions and expectations," 1990.

[6] M. B. Miles, A. M. Huberman, M. A. Huberman, and M. Huberman, Qualitative data analysis: An expanded sourcebook. sage, 1994. 